УдК 338.242:314.74

JEL classification: E60, J60, J61

\section{Ольга МУЛЬСКА}

кандидат економічних наук, старший науковий співробітник, ДУ «Iнститут регіональних досліджень імені М. І. Долішнього НАН України», Україна E-mail: oliochka.mulska@gmail.com http://orcid.org/0000-0002-1666-3971 http://www.researcherid.com/rid/ABA-72032020

(с) Ольга Мульска, 2021

\section{Отримано: 02.05.2021 p.}

Прорецензовано: 15.05 .2021 p.

Рекомендовано до друку: 26.05.2021 p. Опубліковано: 26.05.2021 p.

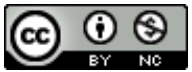

Ця стаття розповсюджується на умовах ліцензії Creative Commons AttributionNonCommercial 4. 0, яка дозволяє необмежене повторне використання, розповсюдження та відтворення на будь-якому носії, за умови правильного цитування оригінальної роботи.
Ольга Мульска (Україна)

\section{МІГРАЦІЙНІ РИЗИКИ ТА ЗАГРОЗИ СТАБІЛЬНОГО РОЗВИТКУ НАЦІОНАЛЬНОÏ ЕКОНОМІКИ ЯК СТРАТЕГІЧНІ ОБ’ЄКТИ ПОЛІТИКИ РЕГУЛЮВАННЯ}

\author{
АНОТАЦІя
}

Вступ. Стабільний розвиток національної економіки в умовах глобалізації, а відповідно і високого рівня міграційної активності населення, корелює із ефективністю державної політики управління міграційними процесами. Соціально-економічні результати політики регулювання визначаються проактивними механізмами управління міграційними ризиками і загрозами, які мають суттєвий вплив на соціально-економічну та демографічну систему країни (обсяги ВВП, рівень інфляції, споживчий попит, капіталізація людського потенціалу, чисельність населення тощо).

Мета. Ідентифікація міграційних ризиків і загроз для країни-донора та країни-реципієнта людських ресурсів як елемент забезпечення стабільного розвитку національної економіки.

Метод (методологія). Теоретичною і науково-методичною основою дослідження стали теорії міграціології, сек'юритизації, економічного розвитку та ризик-менеджменту. У процесі дослідження використано такі методи та підходи як логічного узагальнення і синтезу для формування основних висновків і пропозицій дослідження; графічний - візуалізації результатів ідентифікації міграційних ризиків і загроз.

Результати. Встановлено, що міграційні ризики - це втрати економічної системи та соціальної сфери країни внаслідок відтоку людських ресурсів і негативні наслідки, які виникають у результаті неефективного управління міграційними трансфертами. Міграційні ризики для країни-донора виокремлено у розрізі двох каналів (грошових трансфертів і людських ресурсів). Із врахуванням каналу відтоку людських ресурсів ідентифіковано три сфери міграційних загроз - демографічну (поглиблення демографічної кризи, відсутність капіталізації детермінант людського потенціалу, збільшення кількості розлучень, падіння показників шлюбності, зростання рівня смертності серед економічно активного населення, погіршення складу чисельності населення, депопуляція поселень), соціальну (відтік інтелектуальної еліти, поглиблення соціальної нерівності, дефіцит працівників робітничих професій, поширення соціального сирітства, дистантних та мультинаціональних сімей, зникнення середнього класу, девальвація вищої освіти) та економічну (зменшення ВВП, посилення диспропорції ринку праці, збільшення рівня інфляції за рахунок підвищення купівельної спроможності, зменшення доходів бізнесу, трансформаційні зміни на ринку капіталу та праці), посилення яких веде до виникнення системних ризиків.

Мульска, О. Міграційні ризики та загрози стабільного розвитку національної економіки як стратегічні об'єкти політики регулювання. Економічний аналіз. 2021. Том 31. № 2. С. 34-43.

DOI: https://doi.org/10.35774/econa2021.02.034

Ключові слова: міграційні процеси; ризики; національна економіка; міграційні трансферти; людські ресурси. 


\section{UDC 338.242:314.74}

JEL classification: E60, J60, J61

\section{Olha MULSKA}

PhD in Economics, Senior Researcher, Dolishniy Institute of Regional Research of the National Academy of Sciences of Ukraine, Ukraine

E-mail: oliochka.mulska@gmail.com http://orcid.org/0000-0002-1666-3971 http://www.researcherid.com/rid/ABA-72032020

\section{(c) Olha Mulska, 2021}

\section{Received: 02.05.2021}

Revised: 15.05.2021

Accepted: 26.05.2021

Online publication date: 26.05 .2021

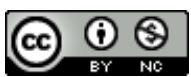

This is an Open Access article, distributed under the terms of the Creative Commons AttributionNonCommercial 4. 0 license, which permits unrestricted re-use, distribution, and reproduction in any medium, provided the original work is properly cited.
Olha Mulska (Ukraine)

\section{MIGRATION RISKS AND THREATS TO STABLE DEVELOPMENT OF THE NATIONAL ECONOMY AS STRATEGIC OBJECTS OF REGULATORY POLICY}

\section{ABSTRACT}

Introduction. Stable development of the national economy in the context of globalization, and consequently the high level of migration activity of the population, correlates with the effectiveness of state policy of migration management. Socio-economic results of regulatory policy are determined by proactive mechanisms for managing migration risks and threats that have a significant impact on the socio-economic and demographic system of the country (GDP, inflation, consumer demand, capitalization of human potential, population, etc.).

Purpose. Identification of migration risks and threats for the donor country and the recipient country of human resources as an element of ensuring the stable development of the national economy.

Method (methodology). Theories of migration, securitization, economic development, and risk management became the theoretical and scientificmethodical basis of the research. During research it is used such methods and approaches as logical generalization and synthesis are used for formation of the basic conclusions and offers of research, graphic for visualization of the results of identification of migration risks and threats.

Results. It is established that migration risks are losses of the economic system and social sphere of the country due to the outflow of human resources and negative consequences that arise because of inefficient management of migration transfers. Migration risks for the donor country are divided into two channels (money transfers and human resources). Considering the channel of human resources outflow, three spheres of migration threats were identified: demographic (deepening demographic crisis, lack of capitalization of human potential determinants, increasing divorce rates, declining marriage rates, rising mortality rate among economically active population, population decline, social depopulation). outflow of intellectual elite, deepening social inequality, shortage of workers, spread of social orphanhood, distant and multinational families, disappearance of the middle class, devaluation of higher education) and economic (reduction of GDP, increasing labour market imbalance, increasing inflation due to inflation), reduction of business income, transformational changes in the capital and labour markets), the strengthening of which leads to systemic risks.

Mulska, O. (2021). Migration risks and threats to the stable development of the national economy as strategic objects of regulatory policy. Economic analysis, 31 (2), 34-43.

DOI: https://doi.org/10.35774/econa2021.02.034

Keywords: migration processes; risks, national economy; migration transfers; human resources. 


\section{Вступ}

Міграція як реальність сучасного суспільства має соціально-економічні, суспільно-політичні, медикодемографічні та ін. наслідки, $€$ чинником стимулювання розвитку економічної кон'юнктури й інструментом регулювання регіональних дисбалансів і локальних ринків праці. Так, одним 3 головних позитивних наслідків міжнародної міграції $€$ інвестиційні надходження в економіку через фінансові трансферти мігрантів, які у певній мірі можуть компенсувати негативні ефекти «відтоку мізків» та інтенсивного потоку робочих кадрів. Грошові перекази мігрантів збільшують національний дохід країни i, як результат, відбувається підвищення не лише рівня життя населення, але й економічного розвитку за рахунок зростання обсягів споживання й інвестицій. Незважаючи на позитивні фінансово-інвестиційні ефекти міграції, у медико-демографічній і соціально-економічній сферах міграція породжує ризики, кумуляція яких призводить до психологічних, політичних, релігійних та системних загроз. Оскільки міграція не є екзогенною змінною, а невід'ємною частиною соціальних процесів та етапів розвитку країни, міграційні ризики щодо економічного розвитку не $є$ однорідними.

Наукова дискусія щодо міграційних ризиків та економічного розвитку склалася окремо від загальної теорії міграції. Оскільки міграційні ризики оцінюють диференціально як для суспільства загалом, так і для економічної системи, класичні теорії міграції не дають цілісного уявлення про ризикогенність міграційних процесів і загроз, які виникають на різних етапах розвитку економіки тих країн, які є експортерами людських ресурсів.

Міграційні процеси і економічний розвиток країни, а відтак і ризики та загрози, які породжують міграція, $€$ взаємозалежні та взаємопов'язаними категоріями. У науковому дискурсі дефініція «ризику» має різні трактування, зокрема як небезпека, невизначеність, втрата, ймовірність, загроза, збиток, випадковість, негативний наслідок. Представники класичної теорії ризику (Дж. Мілл, Н. Сенсор, Л.Н. Непман) під ризиком вбачали втрати у процесі виникнення несприятливих ситуацій, які пов'язані зі здійсненням певного рішення. Натомість представники неокласичної теорії ризику (Т. Бачкаї, Д. Мессен, А. П. Альгін) вивчали ризик як імовірність відхилення від цілі, заради досягнення якої приймається рішення.

В. Абчук досліджував ризик як діяльність або дію з подолання невизначеності [1]. Натомість, В. Чалий-Прилуцький ототожнював ризик до дії (вчинку), коли у випадку невдачі $€$ можливість опинитися в ще гіршому становищі [2]. Схожої позиції дотримуються Г. Чернова й А. Кудрявцева, які інтерпретували ризик як схильність до можливості економічних і фінансових втрат, фізичного збитку, ушкоджень, зволікання як наслідок невизначеності, пов'язаної з обраною траєкторією поведінки [3]. Я. Волоско трактує ризик інтенсивної міграції населення ії наслідками, одночасно визначаючи зовнішню міграцію як чинник дестабілізації та дестимулятор розвитку економіки [4].

Особливої позиції щодо трактування міграційних ризиків дотримується У. Садова, яка визначає міграційний ризик як «міру виникнення певної небажаної ситуації (події) та наслідків прийняття рішень щодо переміщення населення як на мікро-, так і мезо- та мега- рівні» [5, с. 167].

Вплив інтенсифікації міграційних процесів на соціально-економічний розвиток через виявлення міграційних ризиків та ефектів детально проаналізовано у працях Е. Лібанової, Б. Волмера, О. Малиновської, О. Позняка [6; 7; 8]. Водночас, моделювання впливу на міграційних ризиків та ефектів на соціально-економічний розвиток і демографічну сферу представлене у працях науковців Львівської школи регіоналістики [9; 10]. У них підкреслюється висока залежність економічного зростання регіонів України, особливо прикордонних територій, від ефективності використання міграційних трансфертів і капіталізації людського потенціалу мігрантів.

\section{Мета статті}

Метою статті $\epsilon$ ідентифікація міграційних ризиків i загроз для країни-донора та країниреципієнта людських ресурсів як елемент забезпечення стабільного розвитку національної економіки. Для досягнення мети в статті окреслено такі завдання: визначити сфери впливу міграційних загроз для країни-донора у фокусі каналу відтоку людських ресурсів, ідентифікувати ефекти міграційних трансфертів на мікро- і макрорівнях, виявити міграційні загрози та ефекти впливу на економічне зростання країни-донора людських ресурсів через канал міграційних трансфертів.

\section{Виклад основного матеріалу дослідження}

Міграційні ризики - це втрати економічної системи та соціальної сфери, які країна отримує внаслідок відтоку людських ресурсів, та негативні наслідки, які виникають у результаті неефективного управління міграційними трансфертами. Так, у контексті дослідження міграційних процесів доцільно виділити три підходи до трактування поняття «міграційні ризики»: (1) негативні наслідки для країни-донора та країни-реципієнта людських ресурсів як деструктивні чинники змін соціальноекономічної системи та демографічної ситуації; (2) соціально-економічні, фінансові, демографічні, 
суспільно-ціннісні, культурні та ін. втрати країни; (3) ймовірність настання несприятливих соціальноекономічних, медико-демографічних, політикоправових та релігійно-культурних умов, які сприятимуть виштовхуванню населення за кордон. Відтак, міграційні ризики варто диференціювати в контексті національного і регіонального рівнів як фінансові, соціально-економічні, демографічні втрати, ймовірність послаблення економічної безпеки країни та порушення дисбалансів ринку праці; та індивідуального рівня мігранта (рівень домогосподарства), як ризик опинитися в невизначеній ситуації, яка сприятиме виникненню непередбачуваних подій, пов'язаних 3 втратою здоров'я, соціального капіталу, зниження рівня людського розвитку та виникнення криміногенних ситуацій.

Тригером міграційного ризику $€$ його ймовірнісна природа. Поряд з цим міграційному ризику притаманні риси економічності (міграційний ризик пов'язаний з дохідністю й втратами економічної системи країни-донора та країни реципієнта), резервності (рівень міграційного ризику коливається у визначеному діапазоні, відповідно наслідками можуть бути як негативні, так і позитивні ефекти) і невизначеності ступеня ризику, який залежить від параметрів часу, економічних факторів і психологічних чинників.

Теоретико-методологічною прогалиною у науковому дискурсі щодо дослідження міграційних ризиків залишається їхня ідентифікація за каналами поширення, а також розробка методичного інструментарію дослідження ступеня впливу ризиків інтенсифікації міграційних процесів на розвиток економічної системи. Наголосимо, що міграційні процеси впливають на економічний розвиток країни через два канали: людські ресурси та міграційні трансферти. Відтік людських ресурсів породжує ризики у демографічній ситуації та ринку праці, що у довгостроковому періоді має каузальний зв'язок з ВВП, національним доходом, рівнем інноваційно-технологічної конкурентоспроможності країни тощо. Таким чином, міграційні загрози виникають у країнах походження мігрантів, якщо відтік значної частини кваліфікованої робочої сили відбувається одночасно зі старінням населення, що має значний вплив на обсяги виробництва та продуктивність праці і призводить до зниження конкурентоспроможності національної економіки.

У підсумку можна ідентифікувати три сфери міграційних загроз (демографічну, соціальну та економічну) 3 врахуванням каналу відтоку людських ресурсів, посилення яких веде до виникнення системних ризиків (інтенсифікація неконтрольованих міграційних процесів, зростання обсягів нелегальної міграції, вимивання людського потенціалу, суспільно-політична нестабільність) (рис. 1).

Примітно, що міграційні ризики спричиняють зміни в пропозиції робочої сили та продуктивності праці, а також викликають ендогенні поведінкові або політичні реакції, оскільки країни-донори зазвичай пристосовуються до поточних загроз. Міграційні виклики призводять до зменшення рівня доступності трудових ресурсів, депопуляції населення, у короткостроковій перспективі визначають зміни у людському капіталі. Натомість, у середньостроковому лазі міграційні ризики можуть набувати позитивного характеру, стимулювати до підвищення кваліфікації, що сприяє зростанню продуктивність праці. Такі міграційні ризики, які виникають через канал людських ресурсів також впливають на економічну безпеку країни.

Натомість міграційні трансферти мають прямий і короткостроковий вплив на економічний розвиток як на національному так і на особистісному рівні. Еміграція і грошові трансферти розглядаються як наслідки низького рівня соціально-економічного розвитку країни-донора людських ресурсів. Більше того, прямий взаємозв'язок міграції і грошових трансфертів можна розглядати як сприятливий ефект для подолання деструктурних змін в економічній системі, зменшення рівнів бідності та соціальної нерівності, що призвели до трудової еміграції. Таким чином, в умовах відсутності економічного зростання і джерел зовнішніх інвестицій грошові перекази мігрантів стають альтернативою розвитку через мультиплікаційні ефекти для фінансування виробничих інвестицій. Зокрема, В умовах соціально-економічної нестабільності міграційні трансферти $\epsilon$ фінансовими засобами покращення добробуту населення і забезпечення соціально-економічної рівноваги.

Із макроекономічної точки зору міграційні ризики для країни експортера людських ресурсів через канал грошових трансфертів можна ідентифікувати у контексті двох підходів: індивідуальних і капітальних грошових трансфертів (продуктивні). Така систематизація дозволяє виявити вагову значущість і загрози для розвитку національної економіки залежно від характеру їхнього впливу. 


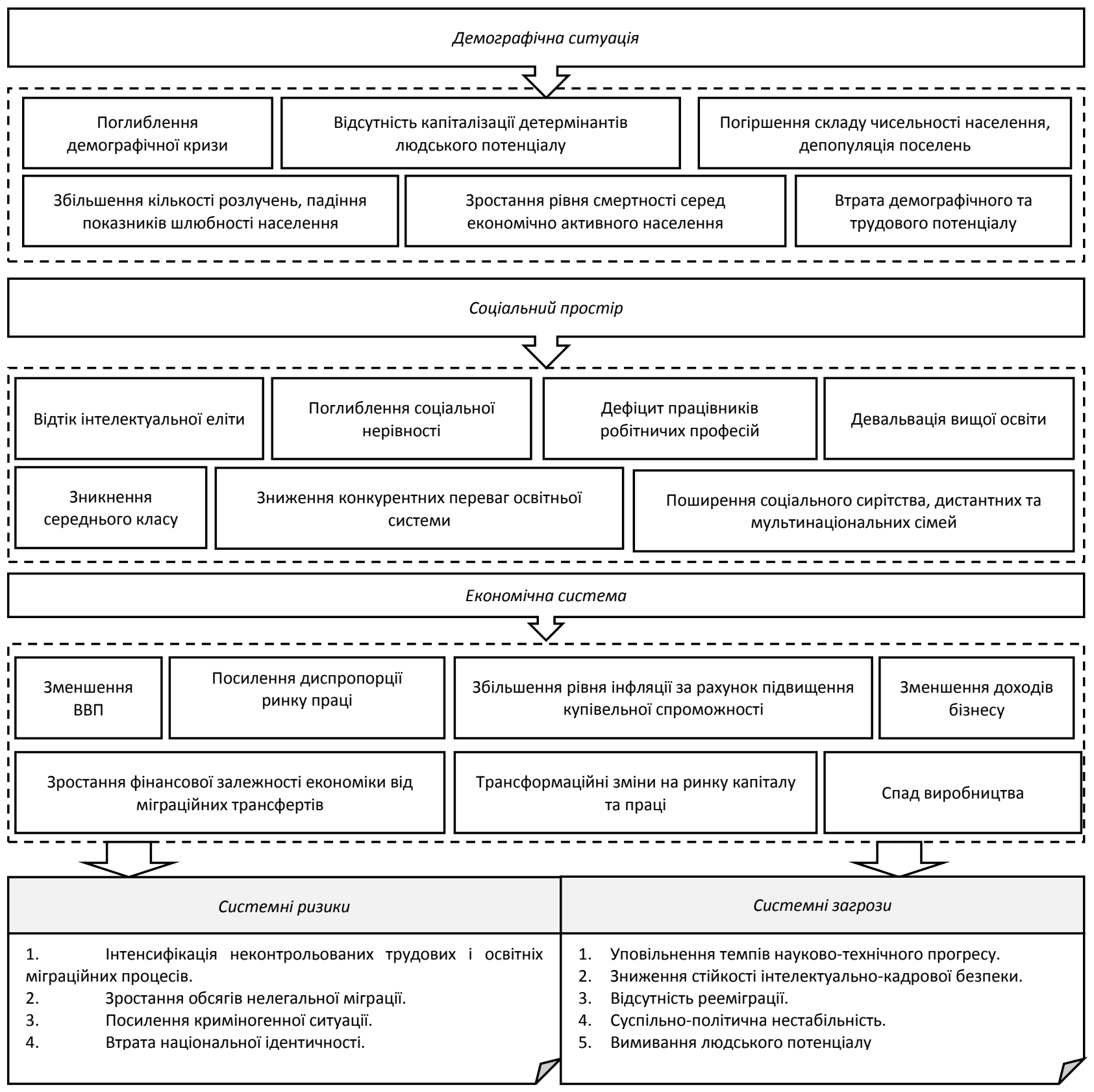

Рис. 1. Сфери впливу міграційних загроз для країни-донора: канал відтоку людських ресурсів

Джерело: авторська розробка.

Індивідуальні міграційні трансферти є прямими переказами для сімейного використання, споживання і заощадження. Продуктивні міграційні трансферти, з іншого боку, відповідають різним формам приватних або соціальних інвестицій, які не $\epsilon$ елементами сімейного бюджету. Така диференціація випливає 3 макроекономічної структури та дозволяє концептуалізувати можливі міграційні ризики та загрози. Наприклад, грошові перекази мігрантів сприяють підтримці балансу витрат і доходів домогосподарств, а вплив на економічний розвиток території може відбуватися різними та взаємодоповнюючими шляхами: міграційні трансферти сприяють елімінації рівня життя, індивідуального споживання і добробуту, одночасно впливаючи на рівень місцевої, регіональної та національної економіки через зростання доходів малого та середнього бізнесу та ін. Капітальні грошові трансферти сприяють нарощуванню обсягів заощаджень і забезпеченню інвестиційного балансу. Інвестиційні виробничі міграційні трансферти як інструмент економічного зростання, який разом з іншими інвестиційними фондами (іноземні прямі інвестиції, приватні внутрішні інвестиції, державні інвестиції тощо) складають основу регулювання економічного розвитку (рис. 2). 


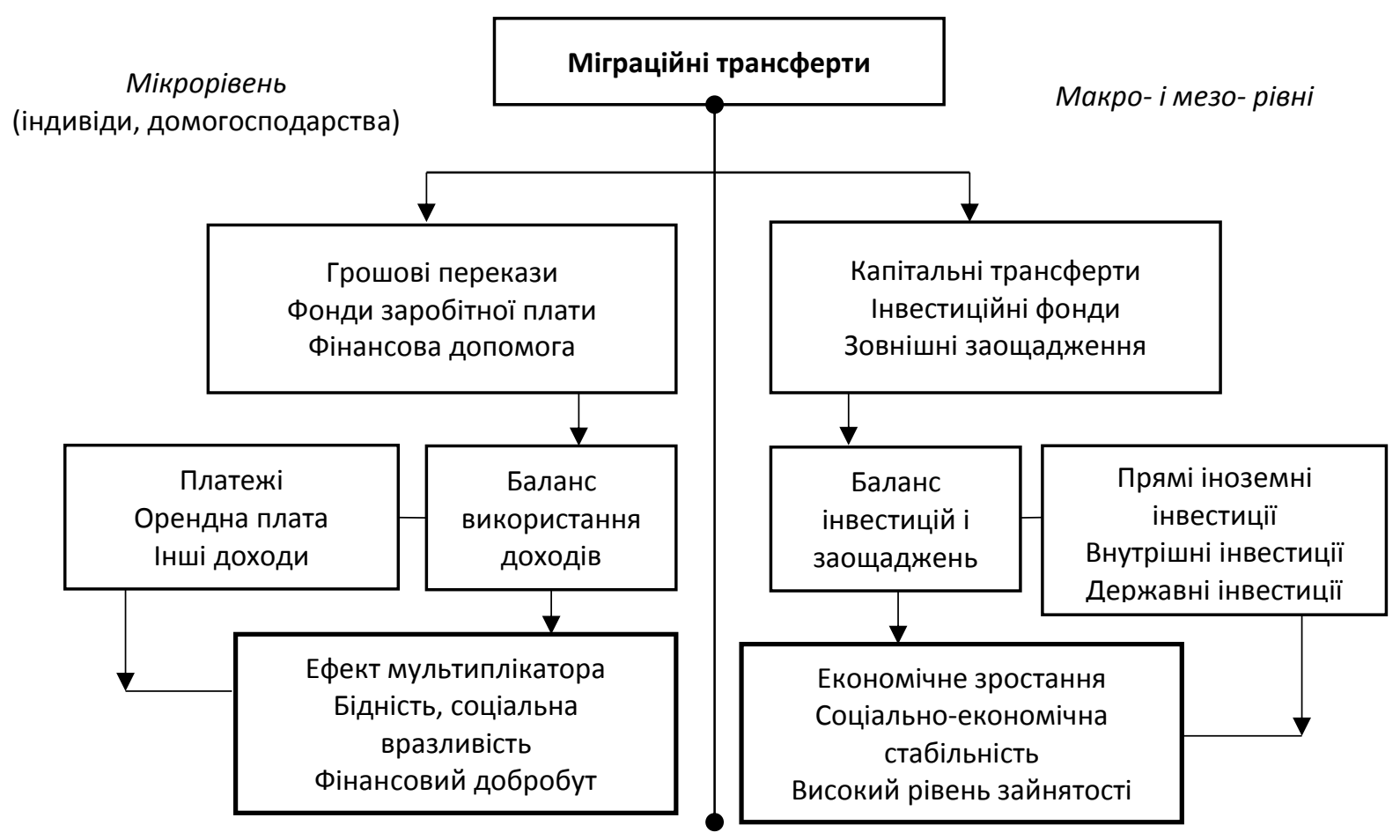

Рис. 2. Ефекти міграційних трансфертів: мікро- і макрорівні

Джерело: авторська розробка.

У більшості досліджень щодо міграційних трансфертів наведено аналіз впливу обсягів грошових переказів на зміни макроекономічних умов приймаючих країн, ніж вплив на розвиток країни-донора людських ресурсів. Зокрема міграційні перекази позитивно впливають на економічне зростання і на кредитний рейтинг країни експортера людських ресурсів, забезпечуючи важливе і стабільне джерело іноземної валюти, яка може сприяти покращенню інвестиційного іміджу та подоланню кризи платіжного балансу. Грошові перекази сприяють ефективному розподілу ресурсів у країні-донора міграційного потенціалу, стимулюючи тим самим сукупний попит на товари та послуги, збільшуючи продуктивність, що створюється за рахунок споживання й інвестицій, збільшуючи доходи та продуктивність за рахунок зменшення рівня безробіття - мобільність безробітних.

Примітно, що деякі дослідники вважають, що потік грошових переказів негативно впливає на економічне зростання країни [11], оскільки міграційні трансферти $€$ фактором, який стимулює імпорт іноземних товарів, сприяє заміщенню товарів внутрішнього виробника, перевищенню споживання імпортної продукції над вітчизняною. Натомість на науковому фронті присутні дослідження, у яких виявлено зв'язок розвитку національної економіки та міграційних трансфертів залежно від часового лагу, який має домінуючий вплив на темпи економічного зростання країни, а не обсяги міграційних трансфертів [12]. Так, численні дослідження щодо короткострокового впливу міграційних переказів на фінансовий розвиток у країнах-донорах людських ресурсів демонструють позитивні ефекти для країн 3 низькими рівнем розвитку [13], натомість для країн з високими рівнем соціально-економічного розвитку позитивні ефекти спостерігають у довгостроковому лазі.

Міграційні трансферти можуть виступати фінансовими інвестиціями для розвитку людського капіталу, стимулювання оптимального споживання і забезпечення мультиплікативного ефекту завдяки збільшенню витрат домогосподарств. Грошові перекази мігрантів виступають драйверами зростання інвестиційного потенціалу, пом'якшення кредитних обмежень в країні, зменшення волатильності споживання, сприяння забезпеченню стабільного макроекономічного середовища, і тим самим, позитивно впливають на економічне зростання. Можна припустити, що міграційні ризики за каналом грошових трансфертів будуть мінімальними для економіки країни-донора, а міграційні ефекти - максимальними за умови розвиненої фінансової системи.

Існують емпіричні докази того, що грошові перекази можуть також мати негативний вплив на зростання в країнах-отримувачах, зменшуючи стимули до праці, а отже, зменшуючи пропозицію робочої сили або участь робочої сили. Це може спричинити зростання реального обмінного курсу в 
країнах-донорах, зменшення пропозиції робочої сили, її продуктивності та стимулів до праці, що, у свою чергу, уповільнює економічне зростання. Так, у дослідженнях Е. Родрігеса і Е. Тіонгсона [14] виявлено, що домогосподарства, членами яких $\epsilon$ трудові мігранти, зменшили рівень зайнятості та продуктивності праці; а у дослідженнях Дж. Айрола [15] підтверджується теза про реверсну еластичність міграційних трансфертів і пропозиції робочої сили в Мексиці. Результати аналізу А. КоксЕдвардса [16] і К. Амуедо-Доренцес [17] також підтверджують негативний вплив грошових переказів мігрантів на рівень неформального ринку праці. Кошти, які мігранти відправляють, витрачаються на поточне споживання, що може бути руйнівним для економіки та посилити соціальну нерівність і фінансову асиметрію між домогосподарствами, які їх отримують, та тими, хто не має цих доходів.

Варто зауважити, що Р. Левіт дотримується думки, що міграційні ризики стосуються не лише національної економіки, тому ввів у науковий дискурс дефініцію “соціальні трансферти» для опису позаекономічних трансфертів - ідеї, знання, досвід та ін. [18]. На відміну від грошових переказів, соціальні грошові перекази мігрантів циркулюють систематично, зокрема під час рееміграції, реверсної міграції, спілкування зі громадами та діаспорою.

Загалом, міграційні процеси мають позитивні ефекти на соціально-економічну систему країни (зменшення дисбалансів національного ринку праці (зниження рівня безробіття), збільшення інвестицій у сферу освіти, зниження бюджетного навантаження за рахунок виплат по безробіттю та інших бюджетних витрат (освіта, охорона здоров'я), зростання рівня добробуту/зниження рівня бідності населення за рахунок міграційних трансфертів, зростання внутрішнього споживчого попиту, капіталізація людського потенціалу (здобуття навичок, досвіду, підвищення кваліфікації та ін.)), а також ризики для демографічної ситуації в країнідонорі (зменшення чисельності населення, зокрема частки молоді, скорочення обсягів трудових ресурсів та висококваліфікованих фахівців), інноваційної сфери (поширення технологічного регресу, зниження інноваційної конкурентоспроможності), економічної системи (зменшення обсягів ВВП, можливе зростання інфляції). Примітно, що негативні та позитивні ефекти міграційних процесів $\epsilon$ соціальноекономічними ризиками, управління якими має стати стратегічним об'єктом державного регулювання розвитку економіки країни (рис. 3).

Міграційні ризики, які пов'язані зі змінами пропозиції робочої сили, приводять до виникнення окремих економічних ефектів залежно від конкретних структурних характеристик, зокрема умов ринку праці та кредитування, а також якісних ознак міграції (стать, вік, кваліфікація, регіональне походження мігрантів). Наприклад, у країнах з великим запасом некваліфікованої робочої сили та високим рівнем некваліфікованого безробіття міграція не матиме значного впливу на продуктивність праці, оскільки безробітні або некваліфіковані працівники заповнюють робочу силу мігрантів. Однак, якщо у країні відсутній «ефект заміщення», то міграція має негативний вплив на обсяги ВВП і продуктивність праці.

\section{Висновки та перспективи подальших розвідок}

Головними ризиками та загрозами поширення міграції населення $€$ неконтрольовані міграційні потоки, інтенсифікація яких має негативні наслідки для ринку праці, сфери виробництва, національної та економічної безпеки, кредитного ринку та ринку інвестиційного капіталу; перебування значної частини мігрантів у сфері тіньового або напівтіньового ринку праці, формування групи прекаріату; відсутність організаційно-економічного механізму регулювання міграційних процесів у частині забезпечення інтересів країни. Важливе значення у державній політиці управління міграційними процесами має класифікація міграційних ризиків із такими ключовими ознаками, як канали, сфери та масштаби впливу, форми прояву, ступені обґрунтованості, причини, джерела та рівні виникнення, характер і термін дії. 
Соціально-економічні зміни

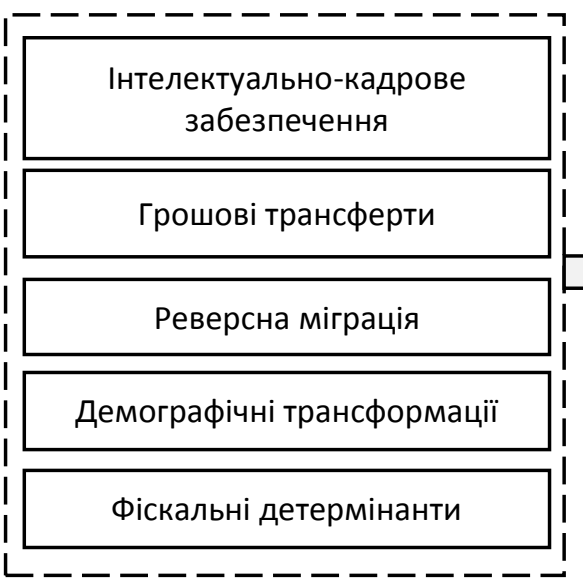

Структурні сфрери впливу

Об'єкти міграчійного ризику

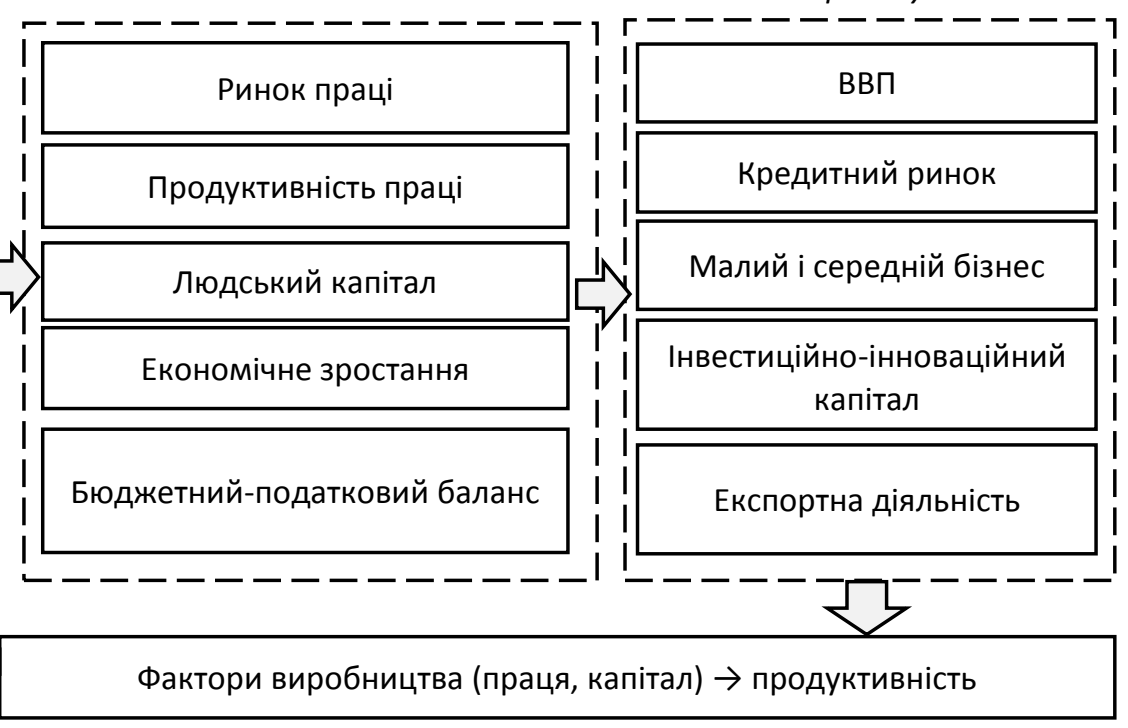

\section{Міграційні загрози}

1) Великі потоки грошових переказів можуть призвести до подорожчання валюти, що матиме негативні наслідки для експорту.

2) Дестабілізація слабких економічних систем.

3) Зростання рівня інфляції.

4) Поглиблення ендогенно соціально-економічної та

орієнтованої асиметрії.

\section{Міграційні ефекти}

1) Збільшення національного доходу, якщо грошові перекази перераховуються за офіційними каналами.

2) Підвищення кредитоспроможності країни на міжнародних кредитних ринках.

3) Стабілізація національних рахунків платіжного балансу.

4) Посилення інноваційно-технологічної конкурентоспроможності країни

1) Формування попиту на імпортовані (а не місцеві) товари.

2) Збільшення рівня інфляції, особливо у сфері будівництва, освіти.

3) Банкрутство малого та середнього бізнесу.

4) Зменшення пропозиції робочої сили.

5) Зменшення продуктивності праці.

1) Посилення місцевої економіки шляхом стимулювання споживання, попиту на місцеві товари чи послуги, сприяння створенню робочих місць.

2) Реінвестування у малі підприємства.

3) Розвиток ринку капіталу.

4) Зменшення рівня економічної і фінансової депривації.

\section{СПИСОК ВИКОРИСТАНИХ ДЖЕРЕЛ}

1. Абчук В.А. Теория риска в морской практике. Л. Судостроение, 1983. 150 с.

2. Чалый-Прилуцкий В. А. Рынок и риск. Методические материалы (пособие для бизнесменов) по анализу, оценке и управлени юриском. Москва: НИУР, ЦентрСинтек, 1994. 213 с.

3. Чернова Г. В., Кудрявцев А. А Управление рисками. Москва: ТК Велби, Проспект, 2005. 160 с.
4. Волоско Я. О. Адміністративноправове регулювання трудової міграції в умовах трансформації економіки України: дис. на здобуття наук. ступеня канд. юрид. наук: спец. 12.00.07 «Адміністративне право і процес; фінансове право; інформаційне право». Львів, 2015. 181 с. С. 4344.
5. Регіональна міграційна політика та механізми їі реалізації / НАН України, Інститут регіональних досліджень; Наук. ред. У. Я. Садова. Львів, 2011. 380 с.

6. Libanova E. Labour migration from Ukraine: key features, drivers and impact. Economics and Sociology, 2019, 12(1), 313-328. DOI: 10.14254/2071-789X.2019/12-1/19. 
7. Vollmer B., Malynovska O. Ukrainian Migration Research Before and Since 1991. Ukrainian Migration to the European Union. 2016. Cham: Springer (pp. 22-32) https://doi.org/10.1007/978-3-31941776-9_2.

8. Libanova E. M., Pozniak, O. V. External labor migration from Ukraine: the impact of COVID-19. Demography and Social Economy, 2020, 4 (42), 25-40. DOI: https://doi.org/10.15407/dse2020.0 4.025 .

9. Levytska O., Mulska O., Ivaniuk U., Kunytska-Iliash M., Vasyltsiv T., Lupak R. Modelling the Conditions Affecting Population Migration Activity in the Eastern European Region: The Case of Ukraine. TEM Journal, 2020, 9(2), 507-514. DOI: 10.18421/TEM92-12.

10. Vasyltsiv T., Lupak R., KunytskaIliash M. Social security of Ukraine and the EU: aspects of convergence and improvement of migration policy. Baltic Journal, 2019, 5 (4), 50-58.
11. Kumar R. R., Stauvermann P. J., Kumar N. N., Shahzad S. J. H. Revisiting the threshold effect of remittances on total factor productivity growth in South Asia: A study of Bangladesh and India. Applied Economics, 2018, 50, 28602877.

https://doi.org/10.1080/00036846 2017.1412074

12. Donou-Adonsou F., Lim S. An empirical analysis of remittance flows into West African Economic and Monetary Union: A panel timeseries approach. Applied Economics, 2015, 48, 1-12. https://doi.org/10.1080/00036846. 2015.1093080

13. Bettin G., Presbitero A.F., Spatafora $K$. Remittances and vulnerability in developing countries. InIMF Working Paper No. WP/14/13; International Monetary Fund: Washington, DC, USA, 2014.

5. Sadova, U. (Ed.) (2011). Rehional'na mihratsiyna polityka ta mekhanizmy yiyi realizatsiyi [Regional migration policy and mechanisms for its implementation]. Lviv: Dolishniy Institute of Regional Research of NAS of Ukraine. Retrieved from: http://ird.gov.ua/irdp/p20110802f. pdf [in Ukrainian].

6. Libanova E. (2019). Labour migration from Ukraine: key features, drivers and impact. Economics and Sociology, 12(1), 313-328. DOI: $10.14254 / 2071-$ 789X.2019/12-1/19.

7. Vollmer, B., \& Malynovska, O. (2016). Ukrainian Migration Research Before and Since 1991. Ukrainian Migration to the European Union. Cham: Springer. https://doi.org/10.1007/978-3-31941776-9_2.

8. Libanova, E. M., \& Pozniak, O. V. (2020). External labor migration from Ukraine: the impact of COVID19. Demography and Social Economy, 4 (42), 25-40. DOI: https://doi.org/10.15407/dse2020.0 4.025 .
14. Rodriguez E. R., Tiongson E. R. Temporary migration overseas and household labor supply: Evidence from urban Philippines. International Migration Review, 2001, 35(3), 709-725. URL: https://www.jstor.org/stable/26758 40.

15. Airola J. The use of remittance income in Mexico. International Migration Review, 2007, 41(4), 850859.

https://doi.org/10.1111/j.17477379.2007.00111.x.

16. Cox-Edwards A., RodríguezOreggia E. Remittances and labor force participation in Mexico: An analysis using propensity score matching. World Development, 2009, 37(5), 1004-1014.

17. Amuedo-Dorantes C., Pozo S. Workers' remittances and the real exchange rate: $A$ paradox of gifts. World development, 2004, 32(8), 1407-1417.

18. Levitt P. Social Remittances: Migration Driven Local-Level Forms of Cultural Diffusion. International Migration Review, 1998, 32(4), 926. DOI:10.2307/2547666

9. Levytska, O., Mulska, O., Ivaniuk, U. Kunytska-Iliash, M., Vasyltsiv, T., \& Lupak, R. (2020). Modelling the Conditions Affecting Population Migration Activity in the Eastern European Region: The Case of Ukraine. TEM Journal, 9(2), 507514. DOI: 10.18421/TEM92-12.

10. Vasyltsiv, T., Lupak, R., \& KunytskaIliash, M. (2019). Social security of Ukraine and the EU: aspects of convergence and improvement of migration policy. Baltic Journal, 5 (4), 50-58

11. Kumar, R. R., Stauvermann, P. J. Kumar, N. N., \& Shahzad, S. J. H. (2018). Revisiting the threshold effect of remittances on total factor productivity growth in South Asia: A study of Bangladesh and India. Applied Economics, 50, 2860-2877. https://doi.org/10.1080/00036846. 2017.1412074

12. Donou-Adonsou, F., \& Lim, S (2015). An empirical analysis of remittance flows into West African Economic and Monetary Union: A panel time-series approach. Applied Economics, 48, 1-12. https://doi.org/10.1080/00036846. 2015.1093080. 
13. Bettin, G., Presbitero, A. F., \& Spatafora, K. (2014). Remittances and vulnerability in developing countries. InIMF Working Paper No. WP/14/13; International Monetary Fund: Washington, DC, USA.

14. Rodriguez, E. R., \& Tiongson, E. R. (2001). Temporary migration overseas and household labor supply: Evidence from urban Philippines. International Migration Review, 35(3), 709-725. Retrieved from:

https://www.jstor.org/stable/26758 40.
15. Airola, J. (2007). The use of remittance income in Mexico. International Migration Review, 41(4), 850-859. https://doi.org/10.1111/j.17477379.2007.00111.x.

16. Cox-Edwards, A., \& RodríguezOreggia, E. (2009). Remittances and labor force participation in Mexico: An analysis using propensity score matching. World Development, 37(5), 1004-1014.
17. Amuedo-Dorantes, C., \& Pozo, S (2004). Workers' remittances and the real exchange rate: $A$ paradox of gifts. World development, 32(8), 1407-1417.

18. Levitt, P. (1998). Social Remittances: Migration Driven Local-Level Forms of Cultural Diffusion. International Migration Review, 32(4), 926. DOI:10.2307/2547666. 